\title{
PERAN DAN PERKEMBANGAN ILUSTRASI
}

\author{
Joneta Witabora \\ Jurusan Desain Komunikasi Visual, School of Design, BINUS University \\ Jln. K.H. Syahdan No. 9, Palmerah, Jakarta Barat 11480 \\ hwijaya@binus.edu
}

\begin{abstract}
Humans are social creature, therefore the need to communicate is the foundation of human nature. Communication has a variety of ways and forms, one of which is to communicate visually. Visual communication is an early form of human expression of the need to interact, and is the origin of the fine arts. The illustration is one of the disciplines that have long existence. The development of the illustration cannot be separated from human history. The world of social and cultural, science and technology has become home to the world of illustration to flourish. Article presents the existence of illustrations, mapping the functions and the roles of illustration provide a more in-depth knowledge in the use of visual imagery.
\end{abstract}

Keywords: illustration role, illustrationn function

\begin{abstract}
ABSTRAK
Manusia adalah makhluk sosial. oleh karena itu kebutuhan berkomunikasi menjadi sifat dasar manusia. Berkomunikasi memiliki berbagai macam cara dan bentuk, salah satunya adalah berkomunikasi secara visual. Komunikasi visual merupakan bentuk awal ekspresi manusia akan kebutuhan berinteraksi dan merupakan cikal bakal dari seni rupa. Ilustrasi adalah salah satu disiplin ilmu yang keberadaanya telah lama. Perkembangan ilustrasi tidak lepas dari perkembangan dalam sejarah kehidupan manusia. Dunia sosial budaya, ilmu pengetahuan dan teknologi telah menjadi tempat berkembangnya dunia ilustrasi. Artikel mengupas keberadaan ilustrasi, memetakan fungsi dan peranannya memberikan pengetahuan yang lebih mendalam dalam memanfaatkan karakter pencitraan.
\end{abstract}

Kata kunci: peran ilustrasi, fungsi ilustrasi 


\section{PENDAHULUAN}

Dengan bentuk yang berbeda keberadaan Ilustrasi telah ada sejak dari dulu. Dari saat anak kecil diperkenalkan dengan buku cerita bergambar sampai saat mereka beranjak remaja dan mulai mengagumi musik dan ilustrasi sampulnya, ilustrasi memainkan peran dalam menentukan kejadian penting dalam periode waktu. Dalam skala yang lebih besar, ilustrasi telah merekam keberhasilan manusia dan menerjemahkannya dengan cara yang tidak bisa dilakukan sebelum adanya fotografi. Dari masa prasejarah dengan lukisan gua memberikan gambaran kehidupan manusia saat itu, lukisan pada masa renaisans, periode revolusi industri dan perkembangan ilmu pengetahuan, periode perang dunia dimana ilustrasi digunakan sebagai alat propaganda, kemunculan konsumerisme setelah perang dunia memicu dunia periklanan, perkembangan industri musik hingga era digital.

Ilustrasi sering bersingungan dengan disiplin ilmu yang lain khususnya seni rupa dan desain grafis. Ini mungkin disebabkan adanya tumpang tindih fungsi dan kebutuhan. Dengan seni rupa mungkin pembedaan yang dapat terlihat jelas yaitu; ilustrasi adalah tentang mengomunikasikan pesan kepada audience. Ilustrasi didasari oleh kebutuhan objektif. Fungsi yang beragam ini menjadikan ilustrasi sebagai bahasa visual yang berpengaruh.

Penulisan ini mencoba untuk menjabarkan fungsi, peranan, sifat dan perkembangan dari dunia ilustrasi. Pemahaman akan kemampuan dari ilustrasi dapat menciptakan karya ilustrasi yang baik, secara nilai estetika maupun secara komunikasi.

\section{METODE PENELITIAN}

Artkel disusun berdasrkan penelitian yang menggunakan metode studi pustaka. Berdasarkan sumber informasi cetak dan elektronik, dikembangkan data dan informasi yang berdasarkan pada pengamatan, hipotesis, dan pengembangan ide dari materi yang ada.

\section{HASIL DAN PEMBAHASAN}

Ilustrasi berasal dari kata latin illustrare yang berarti menerangi atau memurnikan. Dalam kamus The American Heritage of The English Language, illustrate mempunyai arti memperjelas atau memberi kejelasan melalui contoh, analogi atau perbandingan, mendekorasi. Menurut museum ilustrasi nasional di Rhode Island, USA, ilustrasi adalah penggabungan ekspresi personal dengan representasi visual untuk menyampaikan sebuah ide atau gagasan.

Ilustrasi adalah sebuah citra yang dibentuk untuk memperjelas sebuah informasi dengan memberi representasi secara visual. Esensi dari ilustrasi adalah pemikiran; ide dan konsep yang melandasi apa yang ingin dikomunikasikan gambar. Menghidupkan atau memberi bentuk visual dari sebuah tulisan adalah peran dari ilustrator. Mengombinasikan pemikiran analitik dan skill kemampuan praktis untuk membuat sebuah bentuk visual yang mempunyai pesan.

Sepanjang waktu, Ilustrasi telah menjadi sumber dari visualisasi pikiran dan ide dan juga menjadi cara untuk mempengaruhi masyarakat dalam hal keyakinan dan trend. Sejarah ilustrasi tidak bisa lepas dari dunia buku, dimana fungsi awal ilustrasi sebagai penjelas atau pendamping sebuah tulisan. 
Jejak awal ilustrasi bisa terlihat dari catatan visual di gua, manuskrip abad pertengahan sampai buku-buku dan koran diabad ke 15-18 dengan menggunakan teknik cukil kayu, cetak tinggi, etsa dan litografi. Ilustrasi mengalami masa keemasan saat masa revolusi industri sekitar tahun 1890-1920, dimana penemuan mesin cetak membuat media cetak menjadi media komunikasi utama saat itu. Ilustrasi menjadi elemen penting dalam dunia iklan dan cetak. Kemajuan teknologi memberikan kesempatan bereksperimen kepada para ilustrator dalam hal warna dan rendering. Pada masa perang ilustrasi digunakan sebagai poster-poster propaganda.

Tahun 1920-1950 dunia ilustrasi mengalami kemunduran dengan berkembangnya teknologi fotografi. Industri majalah juga sempat mengalami kemunduran dengan adanya televisi. Tahun 1970 ditandai dengan flower generation, generasi muda saat itu memiliki semangat memberontak, ilustrasi menjadi lebih bereksperimental, konseptual memiliki bentuk yang lebih ekspresif. Dengan berkembangnya dunia komputer tahun 1990-an peran ilustrator sempat mengalami kemunduran dengan adanya stock art.

Pada akhir tahun 1990 menuju tahun 2000 dunia ilustrasi kembali menjadi populer di dunia desain dan seni rupa. Ilustrator menemukan peran baru di dunia new media dan animasi. Ilustrator independen yang memiliki ciri khas menjadi seperti selebriti di dunia seni rupa dan desain. Banyak ilustrator tersebut bekerjasama dengan industri menghasilkan produk-produk yang eksklusif. Julian Opie, James Jean merupakan beberapa nama ilustrator yang cukup dikenal karena karakter visualnya. Julian Opie dikenal dengan gaya ilustrasi digital sederhana. Ilustrasinya menggambarkan profil orangorang. Berawal dari mengerjakan ilustrasi untuk cover musik sampai menjadi representasi seniman dalam kampanye produk rokok. James Jean mengawali kariernya di industri komik. Karakter ilustrasinya dengan tema romantik menjadi artwork untuk produk parfum Chanel. Dunia ilustrasi akan terus berkembang dengan banyak bermunculan ilustrator muda, perkembangan teknologi dan media yang memberikan ruang yang luas bagi dunia ilustrasi.

Berdasarkan definisi di atas dapat disimpulkan bahwa ilustrasi memiliki karaktersitik sebagai berikut:

Komunikasi; ilustrasi adalah sebuah gambar yang mengkomunikasikan sebuah konsep atau pesan. Ilustrasi juga dapat berupa opini atau komentar terhadap suatu permasalahan.

Hubungan antara kata dan gambar; ilustrasi pada awalnya berfungsi sebagai pelengkap sebuah teks. Interaksi antarteks dan gambar menciptakan sebuah harmoni. Sejalan perkembangan ilustrasi berkembang dan memiliki peran yang lebih luas dari sekedar pelengkap.

Faktor menggugah; komunikasi visual bertujuan membuat kira merasakan sesuatu, membangkitkan emosi, menghadirkan drama. Faktor ini yang membuat orang merasa ada keterikatan dengan ilustrasi dan yang menentukan apakah ilustrasi itu berhasil atau tidak.

Produksi massal dan media cetak; ilustrasi diciptakan dengan tujuan tertentu dan ditempatkan di media untuk memastikan pesan tersebut sampai. Teknik memproduksi memiliki kekurangan dan kelebihan yang memengaruhi tampilan visual dari ilustrasi. Pengaruh warna juga disesuaikan dengan strategi pemasaran.

Display; tidak seperti seni lukisan, ilustrasi tidak untuk dipanjang atau dipamerkan. Terkadang karya asli ilustrasi memiliki perbedaan dengan hasil akhirnya dikarenakan efek cetak dan juga masalah skala. Medium terbaik untuk menikmati ilustrasi adalah di media-media yang diperuntukkan, seperti di media cetak: majalah, buku, dan lain lain dimana keseluruhan konsep visual terlihat secara lengkap. 


\section{Gambar}

Menggambar adalah prinsip mendasar dalam ilustrasi. Gambar adalah landasan bagaimana pencitraan tersebut terbentuk. Gambar merupakan dasar dari semua gaya ilustrasi, dari realis hingga abstrak. Setiap ilustrasi harus dipahami, dirancang, dan disajikan secara layak untuk dipresentasikan; dan menggambar berperan dalam setiap tahap tersebut. Menggambar juga memberi informasi mengenai identitas ilustrator, mengembangkan, dan membentuk ikonografi pribadi illustrator. Merupakan atribut fungsional yang harus dipunyai seorang ilustrator dan menentukan dasar perbendaharaan visual. Observasi dan belajar mengamati merupakan bagian dari pembelajaran ilustrasi. Penguasaan gambar secara objektif dan analitis akan memberikan pengetahuan secara detail tentang subjek dan menghasilkan imajinasi untuk berkreasi.

Menggambar adalah cara dimana ide divisualisasikan dari konsep hingga hasil akhir. Menggambar bermain dengan komposisi, warna, tekstur, bentuk, skala, ruang, perspektif, aspek emotif, dan asosiatif. Pemahaman objektif dan analitis dalam gambar merupakan dasar utama untuk memahami subjek. Ini adalah keterampilan akademis dan praktis yang penting untuk ilustrator saat merekam informasi dan membangun konsep.

\section{Bahasa Visual}

Dalam berbahasa visual seorang ilustrator dapat diasosiasikan dengan gaya gambar tertentu. Gaya gambar merupakan ciri khas yang terlihat dari karya ilustrasi sehingga menjadi sebuah ikon sang ilustrator. Gaya gambar juga menentukan genre ilustrasi seseorang. Seperti di dunia musik, literatur, seni rupa, dan desain. Gaya gambar memiliki banyak variasi dari tradisional hingga bentuk kontemporer yang bersifat tren. Perkembangan Ilustrasi menghasilkan begitu banyak variasi gaya gambar. Akan tetapi, jika dilihat secara garis besar, bentuk pencitraan dapat dibagi menjadi dua; literal ilustrasi penggambaran secara harafiah, dimana penekanannya terletak pada menghadirkan gambar yang sebenarnya atau yang dapat dipercaya. Bentuk kedua adalah gambar yang bersifat konsep, dimana metafora dapat digunakan sebagai penggambaran sebuah ide.

Kedua bentuk ilustrasi tersebut dapat digunakan diberbagai peran ilustrasi; sebagai informasi, opini, narasi, persuasi, dan identitas. Penggunaan gaya gambar harus disesuaikan dengan isi dan konteks sebuah masalah. Gaya gambar dapat mendukung tercapainya tujuan sebuah ilustrasi.

Visual Metafora; visual metafora dapat dikategorikan sebagai berikut.

Ilustrasi Konseptual; adalah cara atau metode mempresentasikan konten atau ide dalam bentuk komunikasi, ilusi, simbolisasi dan ekspresi. Ilustrasi konseptual banyak digunakan untuk mempresentasikan isu atau tema yang kritis dan kompleks seperti di majalah atau surat kabar. Bahasa visual ini banyak digunakan pada isu-isu yang berhubungan dengan ekonomi, politik, dan sosial.

Secara sejarah gaya gambar realis tergantikan oleh fotografi, sehingga ilustrasi mencari cara untuk merepresentasikan sebuah isu atau topik tidak hanya dari bentuk yang luar saja tapi dapat menangkap inti dari topik tersebut melalui metafora-metafora yang bersifat surealis.

Diagram; adalah ilustrasi yang menggambarkan fitur sebuah objek, system, atau proses. Bentuk ilustrasi ini tidak dapat berdiri sendiri tanpa ada informasi lain yang dipaparkan. Diagram atau info grafis biasa digunakan sebagai sarana edukasi. Sering kita temukan di buku-buku pendidikan.

Abstraksi; adalah bentuk visual yang banyak menggunakan warna dan bentuk dari hasil ciptaan sendiri. Visual yang dihasilkan dengan texture berani bentuk nongeometris maupun geometris, elemen-elemen bebas yang tidak memiliki asosiasi dengan visual yang ada. Abstraksi memiliki bentuk 
yang bebas untuk direpresentasikan. Ilustrasi seperti ini lebih sering digunakan sebagai dekoratif atau pelengkap di poster, cover buku, point of sale dengan penggabungan element teks sebagai satu kesatuan visual.

\section{Pictorial Truth (Penggambaran Realis)}

Secara sejarah, ilustrasi termasuk dalam kategori penyampaian kembali secara harafiah. Jauh sebelum penemuan kamera, ilustrasi adalah satu-satunya bentuk komunikasi visual. Dari lukisan hewan dan manusia di gua, lukisan mesir sampai lukisan jaman romawi yang menggambarkan kehidupan sehari-hari. Pada zaman renaisans penggunaan teknik perspektif, detail arsitektur secara akurat dan perkembangan ilmu dan teknologi memberikan seniman seperti Leonardo da Vinci media untuk menghasilkan karya-karya yang realistik. Ketika zaman ini justru seni rupa memiliki definisi yang mirip dengan ilustrasi. Lukisan maupun bentuk lain seni rupa merupakan pesanan dari gereja maupun bangsawan.

Visual yang dihasilkan merupakan kebenaran apa adanya tanpa penekanan pada konsep, alegori dan metafora, mengutamakan detail yang akurat. Dapat dikatakan definisi gambar atau gambar realis adalah representasi dari sebuah tempat, besar maupun kecil dengan komponen-komponen seperti manusia atau objek lain dengan posisi atau interaksi dalam bentuk visual yang kredibel.

Walaupun begitu, di beberapa buku anak dengan tema sejarah, flora dan fauna maupun fantasi digambarkan dengan cara melebih-lebihkan, komikal dan karikatur. Gambar ini masih dapat digolongkan sebagai gambar dengan sifat realis karena masih memperlihatkan suasana dengan komponen dan interaksi yang masih sesuai dengan dunia nyata. Sifat gambar realis memiliki kualitas yang ideal untuk menciptakan efek drama terutama saat digunakan dalam gambar berkesinambungan seperti grafis novel dan komik strip.

Pada dasarnya, gambar dengan sifat realis dapat dibagi menjadi dua. Ilustrasi linear menggunakan garis untuk membentuk objek, dan ilustrasi tonal menggunakan terang-gelap untuk membentuk objek. Ilustrasi dengan teknik tonal dapat lebih menangkap kesan realistis karena ilusi tiga dimensi yang dicapai dengan teknik tersebut.

Representasi harfiah melalui gambar dapat memberikan kesan realistis dengan tambahan nilai estetika dan imajinasi. Sepanjang sejarah, seniman mencoba mencipta ulang komposisi gambar dengan tingkat detail dan realis yang intens dengan tema yang beragam: politik, agama, budaya, dan kehidupan sehari-hari. Seiring dengan waktu, pemahaman representasi visual dengan penggunaan perspektif, proporsi, skala, dan pemahaman media yang meningkat menghasilkan gambar-gambar dengan tingkat realis yang tinggi. Ilustrasi dengan tingkat detail tinggi tersebut disebut dengan ilustrasi hyperrealistic. Karakter ilustrasi seperti ini menjadi dominan digunakan di dunia ilustrasi komersial seperti di dunia periklanan.

Karakter lain selain hyperrealistic yang juga termasuk gambar realis, yaitu stylized realism yaitu gaya gambar realis dengan representasi yang akurat tetapi penyelesaiannya agak bebas menyebabkan kesan yang berbeda. Seperti pada pemberian warna yang lebih untuk menimbulkan kesan tertentu atau membangkitkan emosi tertentu seperti pada gaya impresionisme.

Ilustrasi dengan bentuk rangkaian gambar juga masih bisa dikategorikan sebagai ilustrasi yang menggambarkan keadaan sebenarnya atau realis. Karena walaupun elemen didalamnya sering dibuat penyimpangan, tetapi masih dalam koridor ruang yang realis. Inti dari gambar berangkai adalah kesinambungan konteks dari setiap gambar untuk menciptakan sebuah pesan. Karakter ilustrasi ini dapat digunakan untuk promosi, iklan, promosi, informasi, editorial di berbagai media cetak. 


\section{Estetika}

Sejarah budaya, gerakan seni dan lain lain memengaruhi perkembangan ilustrasi. Perubahan budaya memberikan ruang pada beberapa gaya ilustrasi untuk diasosiasikan dengan tema atau subjek tertentu. Dalam perjalanannya, ilustrasi bersimbiosis dengan dunia musik, fashion, dan lain lain menciptakan tren yang dapat diterima masyarakat luas.

Dunia fashion menjadi tempat tren ilustrasi berkembang. Pada awalnya, ilustrasi digunakan untuk iklan dan point of sale, kemudian sempat berkurang dengan hadirnya fotografi. Saat ini ilustrasi kembali menjadi alat yang sering dipakai di dunia fashion.

Dalam dunia iklan berkembang ilustrasi yang berupa gabungan hyperrealism dengan nilai sentimental. Istilah karakter ilustrasi seperti ini disebut dengan chocolate box. Tujuannya bermain dengan sensasi indra, memberi kesan berlebihan , sensual bahkan hedonistic. Walaupun dianggap sebagai cara ilustrasi yang banyak menerima kritik karena dianggap lebih menonjolkan permukaan daripada isi, tetapi masih tetap dipakai karena terbukti berpengaruh dalam penjualan produk. Kontradiktif dengan ilustrasi "chocolate box" ada karakter lain yang tujuannya adalah menciptakan reaksi "shock". Dengan memperlihatkan kenyataan yang tidak menyenangkan sehingga menimbulkan kontroversi atau perdebatan. Karakter ini banyak digunakan untuk tema satir dalam dunia publikasi sebagai opini atau komentar.

\section{Peran Ilustrasi}

\section{Ilustrasi sebagai Alat Informasi}

Berawal dari abad ke-19, berkembangnya ilmu pengetahuan dan pendidikan. Ilustrasi dengan bentuk detail, rumit dan garis hitam putih dihasilkan dengan teknik cukil. Ilustrasi digunakan untuk merekam dunia fisik dan intelektual, banyak ditemukan di buku-buku pendidikan, ensiklopedia, dan pengetahuan alam. Ilustrasi digunakan oleh para ilmuwan untuk mendokumentasi dan menjelaskan secara detail subjek yang sedang diteliti, dari kehidupan alam sampai anatomi. Dalam dunia kedokteran ilustrasi medis menghasilkan ilustrasi anatomi dan bendah digunakan untuk tujuan pendidikan dan pelatihan. Ilustrasi jenis ini biasa disebut dengan istilah scientific illustration, bentuk seni untuk kebutuhan ilmu pengetahuan. Merupakan hasil dari representasi dengan diagram dan tingkat akurasi untuk mengomunikasikan semua aspek yang berhubungan dengan ilmu pengetahuan.

Ilustrasi juga digunakan untuk merekronstruksi suatu kejadian yang merupakan kejadian penting dalam sejarah manusia. Dalam hal ini ilustrasi merupakan hasil kerja sama antara para ahli dan ilustrator, sebuah tampilan dari subjek displin dan praktik seni visual. Ilustrasi teknik dapat kita lihat di subjek-subjek yang berhubungan dengan teknologi. Merupakan penjelasan komprehensif tentang pembuatan atau perakitan dengan perhatian utama penjelasn struktur, fungsi dan masalah mekanik. Secara umum, ilustrasi adalah media instruksi yang baik, informasi dapat lebih mudah dicerna ketika disampaikan secara visual. Ilustrasi bekerja dalam berbagai tingkat, ilustrasi dapat menjelaskan dari hal sederhana hingga; memainkan alat musik, olah raga atau permainan sampai ke hal yang kompleks; teknik pemasangan, struktur arsitektur, dll.

\section{Ilustrasi Opini}

Peran ilustrasi ini dapat kita lihat didunia editorial, fungsi utamanya adalah menjadi simbiosis dengan jurnalisme yang terkandung dihalaman koran dan majalah. Ilustrasi menjadi media opini pada tema-tema seperti gaya hidup, politik dan isu-isu yang sedang terjadi. Opini politik dalam bentuk humor ataupun satir bermanifestasi menjadi political cartoon. Ilustrasi editorial merangsang pemikiran dan perdebatan, menyajikan argumen menimbulkan pertanyaan dan membuat pernyataan provokatif. 
Dalam tulisan-tulisan dengan tema gaya hidup dalam sebuah majalah, ilustrasi dibuat dalam bentuk ringan dengan tujuan lebih untuk menghibur.

\section{Ilustrasi sebagai Alat Untuk Bercerita}

Ilustrasi narasi atau cerita banyak kita temui di buku anak, novel grafis, dan komik. Narasi dalam bentuk fiksi yang banyak mengandung fantasi. Di buku-buku untuk dewasa ilustrasi sering digunakan untuk sampul buku. Ilustrasi di sampul buku berfungsi sebagai kemasan dan point of sale.

Komik adalah potrait sebuah cerita melalui ilustrasi yang berkesinambungan. Berawal dari komik strip yang terbit di koran kemudian berkembang dengan komik-komik dengan tema superhero. Dari tema cerita yang diperuntukan untuk anak-anak dan remaja hingga berkembang menjadi tema yang lebih dewasa dengan bobot cerita yang lebih berat yang disebut dengan istilah novel grafis. Peran ilustrasi sebagai sebuah narasi di sebuah komik memberikan pengertian baru dalam hal jeda dan alur.

Gaya ilustrasi di sebuah narasi tergantung dari genre sebuah tulisan. Hal yang harus diperhatikan dalam membuat ilustrasi dalam sebuah narasi adalah menemukan keseimbangan antara teks dan gambar. illustrator harus cermat apakah gambar yang dibuat harus memperlihatkan secara detail bagian dari naskah atau lebih memberi kesan misterius untuk menghasilkan narasi yang menarik. Dialog antara teks dan gambar adalah kunci utama untuk menghasilkan atau menjaga jeda dan alur sebuah narasi.

\section{Ilustrasi sebagai Alat Persuasi}

Kekuatan persuasi tidak bisa dianggap remeh, dan ilustrasi selama ini mengambil peran yang besar dalam hal ini. Peran ilustrasi ini terlihat nyata di dunia komersial periklanan. Ilustrasi iklan atau dulu disebut dengan seni komersial berawal dari visual representasi produk-produk rumah tangga. Sekarang ilustrasi dalam dunia iklan dipakai sebagai bagian dari kampanye sebuah produk untuk membangun kesadaran merek sebuah barang atau perusahaan.

Ilustrasi dalam advertising direncanakan secara detail. Konsep kampanye sebuah produk menjadi landasan bagaiman ilustrasi akan dibuat. Merencanakan komunikasi agar pesan dari sebuah produk tersampaikan ke audience. Demografi audience menentukan gaya ilustrasi yang tepat untuk menyampaikan pesan. Oleh karena itu, ilustrasi dalam bidang periklanan sangatlah luas. Keanekaragaman yang dibutuhkan sangat bervariatif, dari produk jasa, produk makanan, minuman, pakaian, peralatan rumah tangga, kendaraan, media komunikasi dan teknologi, pariwisata, perbankan dan lain lain.

Penggunaan ilustrasi diberbagai media seperti outdoor, cetak dan elektronik memengaruhi bagaimana teknis pembuatan ilustrasi tersebut. Peran ilustrasi sebagai alat persuasi juga dimanfaatkan dalam dunia politik. Sebagai alat propaganda pada masa perang, ilustrasi menjadi sarana efektif menyebarkan pesan.

\section{Ilustrasi sebagai Identitas}

Peran ilustrasi juga digunakan dalam konteks pengenalan produk atau perusahaan. Ilustrator bekerjasama dengan desain grafis dalam penempatan ilustrasi di media below the line, packaging, point of sale dan lain lain. Selain sebagai alat untuk brand recognition, ilustrasi dapat juga digunakan untuk kepentingan identitas perusahaan atau organisasi. Ilustrasi sering digunakan untuk kebutuhan visual dimana mencerminkan identitas perusahaan. Contoh penggunaan ilustrasi sebagai identitas yang paling mudah terlihat bisa dilihat di logo perusahaan. Banyak logo perusahaan menggunakan ilustrasi untuk mencerminkan produk mereka. Selain itu, ilustrasi juga berperan sebagai proyeksi dari visi, misi 
budaya perusahaan, memberikan gambaran lebih dalam perusahaan. Bentuk ilustrasi seperti ini sering dimanfaatkan sebagai elemen interior berupa lukisan-lukisan konsep.

Peran ilustrasi juga banyak digunakan di media retail dan promosi. Ilustrasi memberikan dampak visual terkait dengan informasi dan promosi sebuah produk atau jasa. Ilustrasi sering dimanfaatkan untuk menggambarkan suatu tema yang abstrak seperti produk-produk dari perusahaan keuangan, bank dan lain lain. Kemasan produk merupakan lingkup dimana ilustrasi bisa sangat berperan. Ilustrasi memberikan identitas dan perbedaan dengan kompetitor sejenisnya; membuat sebuah produk lebih menarik sehingga meningkatkan ketertarikan kepada konsumen. Penggunaan ini banyak terlihat di produk produk makanan dan anak-anak. Karakter yang bersifat humor dan menarik dimanfaatkan untuk mempromosikan produk. Beberapa produk makanan memperlihatkan ilustrasi suasana, asal sebuah produk sehingga memberikan kesan atau menekankan kualitas sebuah produk.

Sampul buku seperti juga dengan kemasan produk memberikan bentuk visual yang bisa diasosiasikan dengan isi produk atau tema buku. Pemahaman isi buku sangat penting dalam menentukan visual sampul buku. Cover selain menjadi identitas juga berfungsi sebagai point of sale dan strategi pemasaran. Industri musik dari dulu telah identik dengan penggunaan visual yang kreatif. Berbagai aliran musik, dari era pop, rock, dan psikedelik melahirkan bentuk-bentuk visual dalam desain dan ilustrasi yang mencerminkan era tersebut. Keragaman dalam jenis musik dapat ditampilkan oleh kedalaman bahasa visual ilustrasi untuk setiap genre dengan cara yang inovatif dan segar. Ilustrasi juga menjadi media yang ideal untuk memberi identitas baru kepada musik klasik kontemporer dimana musik tersebut terus direkam ulang dan memiliki berbagai versi.

\section{Ilustrasi sebagai Desain}

Kedekatan hubungaan antara desain dan ilustrasi memberi peluang kepada para ilustrator untuk berperan juga sebagai desainer. Beberapa contoh seperti toki doki sebuah produk ilustrasi hasil ilustrator Simone Legno. Ilustrasi dengan tema fashion diaplikasikan ke dalam produk-produk kaos, tas dan lain lain. Ilustrasi menjadi dasar dalam mendesain produk maupun komunikasi visual lainnya.

\section{SIMPULAN}

Dari pembahasan diatas dapat disimpulkan bahwa displin ilmu ilustrasi akan terus berkembang mengikuti perkembangan dunia. Sebagai alat berkomunikasi, ilustrasi memiliki karakter yang harus dipahami agar pemanfaatan ilustrasi dapat memberikan efek yang diinginkan. Pengetahuan dan kreatifitas bersama dengan penguasaan teknis menjadi dasar dalam penciptaan karya ilustrasi. Saat sekarang ini aplikasi ilustrasi bisa kita lihat dimana-mana. Ilustrasi digunakan diberbagai alat visual komunikasi. Era digital memberikan kemudahan dalam hal teknis pembuatan ilustrasi, dunia internet memberikan kesempatan ekspos secara luas terhadap ilustrasi, para ilustrator mendapatkan kesempatan begitu besar untuk dikenal secara luas. Oleh karena itu pemahaman akan sifat dan peran ilustrasi menjadi penting. 


\section{DAFTAR PUSTAKA}

Alan Male. (2007). Illustration: A Theoritical \& Contextual Perspective. SA: AVA Publishing.

Jaleen Grove. (2011). Evaluating Ilustration Aestetically: Points for consideration for those new to the field. Academia.

Lawrance Zeegen, Crush. (2005). The Fundamental of illustration. SA: AVA Publishing.

Steve Garner. (2008). Writing on Drawing: Essay on Drawing Practice and Research. Bristol UK: Intellect Books. 